\title{
ESCENAS DE LA CORTE DE ALEJANDRO MAGNO Y SU RECEPCIÓN EN LA EDAD MODERNA
}

\author{
Víctor M. Mínguez Cornelles \\ (Universitat Jaume I) \\ minguez@,uji.es
}

\section{RESUMEN}

La imitatio Alexandri que arrancó aun en vida del rey de Macedonia y que alcanzó un enorme éxito en el Imperio Romano a través de los relatos escritos y los retratos de Alejandro, derivó a finales de la Edad Media y a lo largo de la Edad Moderna en una fabricación visual de gran trascendencia a través de la representación de sus gestas en cientos de miniaturas, tapices, pinturas y estampas que, como en la Antigüedad, proyectó un modelo de gobernante a emular. Los temas más habituales recrearon episodios bélicos y heroicos de su campaña asiática, caracterizados por su ejemplaridad. Menos frecuentes fueron las representaciones de escenas cortesanas, quizá porque es en las actividades palatinas donde encontramos al Alejandro más controvertido. En este texto analizo la presentación de algunos de estos instantes más polémicos de su vida en el arte de los siglos XVI, XVII y XVIII.

PALABRAS CLAVE: Alejandro Magno; corte; pintura; Edad Moderna; emulación.

\section{SCENES FROM THE COURT OF ALEXANDER THE GREAT AND ITS RECEPTION IN THE EARLY MODERN AGE}

\begin{abstract}
The imitatio Alexandri, started while the King of Macedonia was still alive and with great success in the Roman Empire -through written accounts and portraits of Alexander-, derived at the end of the Middle Ages and throughout the Early Modern Age in a visual corpus of great significance depicting his deeds in hundreds of miniatures, tapestries, paintings and prints that, as in Antiquity, projected a model of a ruler to emulate. The most common topics recreated were exemplary warfare and heroic episodes of his Asian campaign. Less frequent were the courtly scenes, perhaps
\end{abstract}


because it is in the palatine activities where we could find the most polemic Alexander. In this text we analyze the depiction of some of these controversial moments of his life in the art of the 16th, 17th and 18th centuries.

KEY WORDS: Alexander the Great; court; painting; Early Modern Age; emulation.

Entre 1683 y 1686 el joven y prometedor pintor francés Nicolas de Largillière (1656-1746) - uno de los grandes retratistas de las posteriores cortes de Luis XV y la Regencia- realizó un retrato de su colega Le Brun: Retrato de Charles Le Brun (Musée du Louvre, París) (Fig. 1) ${ }^{1}$. En él contemplamos al artista más relevante e influyente de la corte del rey Sol en la cumbre de su carrera: sentado en un sillón en el centro de su estudio y bajo un cortinaje nos mira directamente mostrándonos con la mano izquierda un boceto de una pintura alegórica de Luis XIV situada sobre el caballete, mientras con la mano derecha sostiene los pinceles. Tras el monarca se amontonan un busto clásico, un orbe y un libro; en una mesa, y debajo de pequeñas reproducciones de esculturas de la Antigüedad, penden dos estampas. Solo se aprecia un fragmento de la que está encima, pero se distingue en él con facilidad el grabado que Gérard Edelinck realizó del cuadro pintado por Le Brun Alejandro y la familia de Dario o Las reinas de Persia a los pies de Alejandro (1662, Musée National du Château de Versailles et de Trianon, Versalles) (Fig. 2). No es extraño que Largillière incorpore la alusión a esta pintura en esta obra que exalta a Le Brun porque fue precisamente la que le proporcionó el reconocimiento de Luis XIV, que tras contemplarla le ennobleció y le convirtió en pintor del Rey.

${ }^{1}$ Esta investigación se enmarca en el proyecto I+D “Arte, realeza e iconografía heroica. La proyección mítica de la monarquía hispánica, siglos XVI-XIX”. Ministerio de Ciencia, Innovación y Universidades. Código: PGC2018-097059-B-I00. 


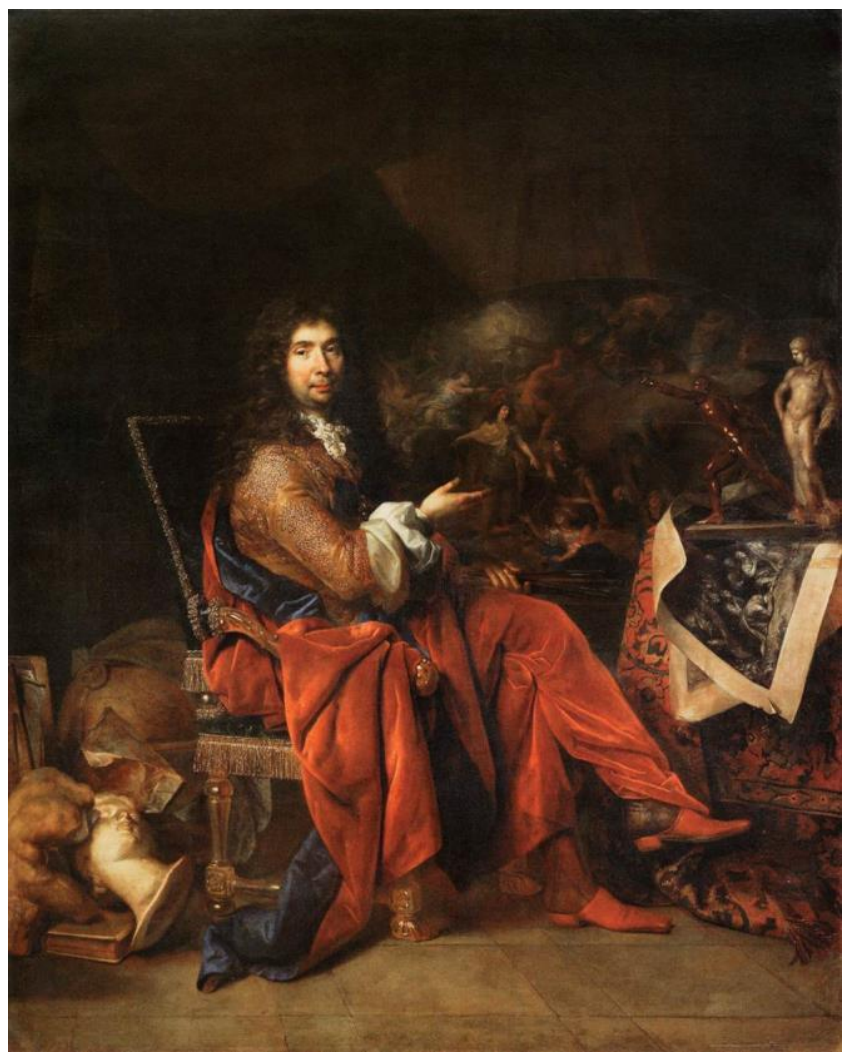

Fig. 1- Nicolas de Largillière, Retrato de Charles Le Brun. 1683-1686, París, Musée du Louvre.

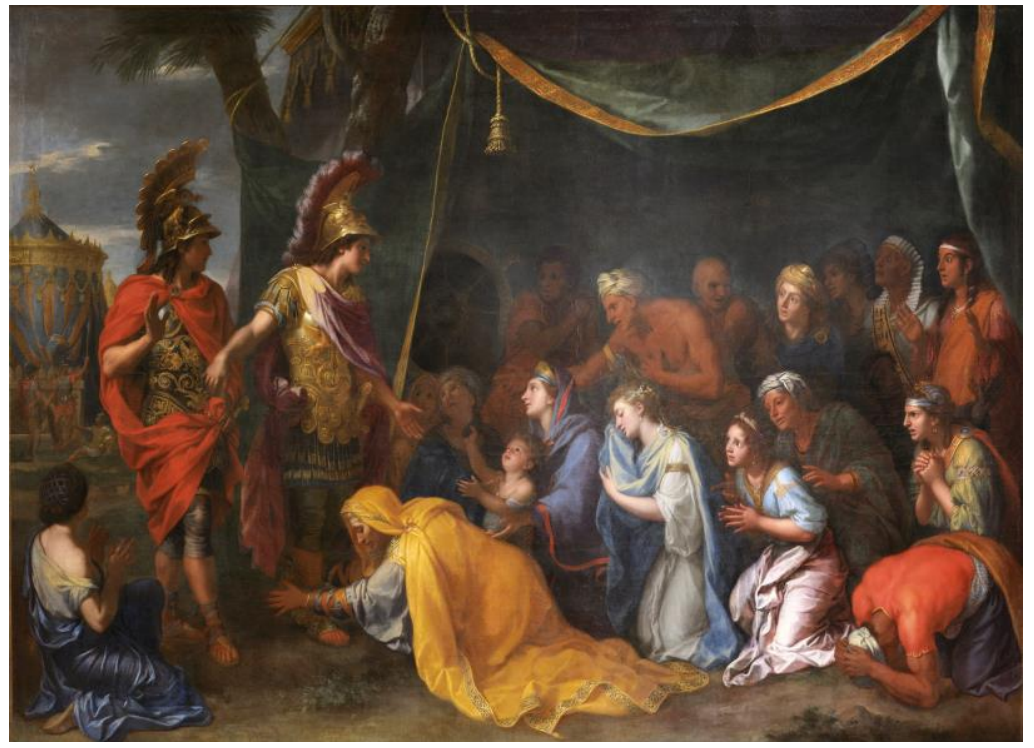

Fig. 2- Charles Le Brun, Alejandro y la familia de Dario o Las reinas de Persia a los pies de Alejandro. 1662, Versalles, Musée National du Château de Versailles et de Trianon. 
El lienzo Alejandro y la familia de Darío representa el momento en que, tras su victoria en Iso sobre el monarca persa, el rey de Macedonia, acompañado de Hefestión, acoge bajo su protección a la madre -Sisigambis-, esposa -Estatira- e hijos -Oco, Estatira-Barsine y Dripetis- de su antagonista, manteniendo sus estatus regios. Popularizada ya en su tiempo gracias a su reproducción en tapices y grabados, y junto a muchas otras composiciones similares de otros artistas sobre este mismo tema realizadas durante los siglos XVII y XVIII, la pintura de Le Brun difundió la clemencia y generosidad de Alejandro Magno en las cortes del Barroco. Da cuenta de su éxito un aguafuerte de Sébastien Leclerc, La visita de Colbert de Villacerf a los Gobelinos (1696, The Metropolitan Museum of Art, Nueva York), que muestra al ministro y su cortejo contemplando precisamente el tapiz que representa esta escena (Fig. 3) ${ }^{2}$.

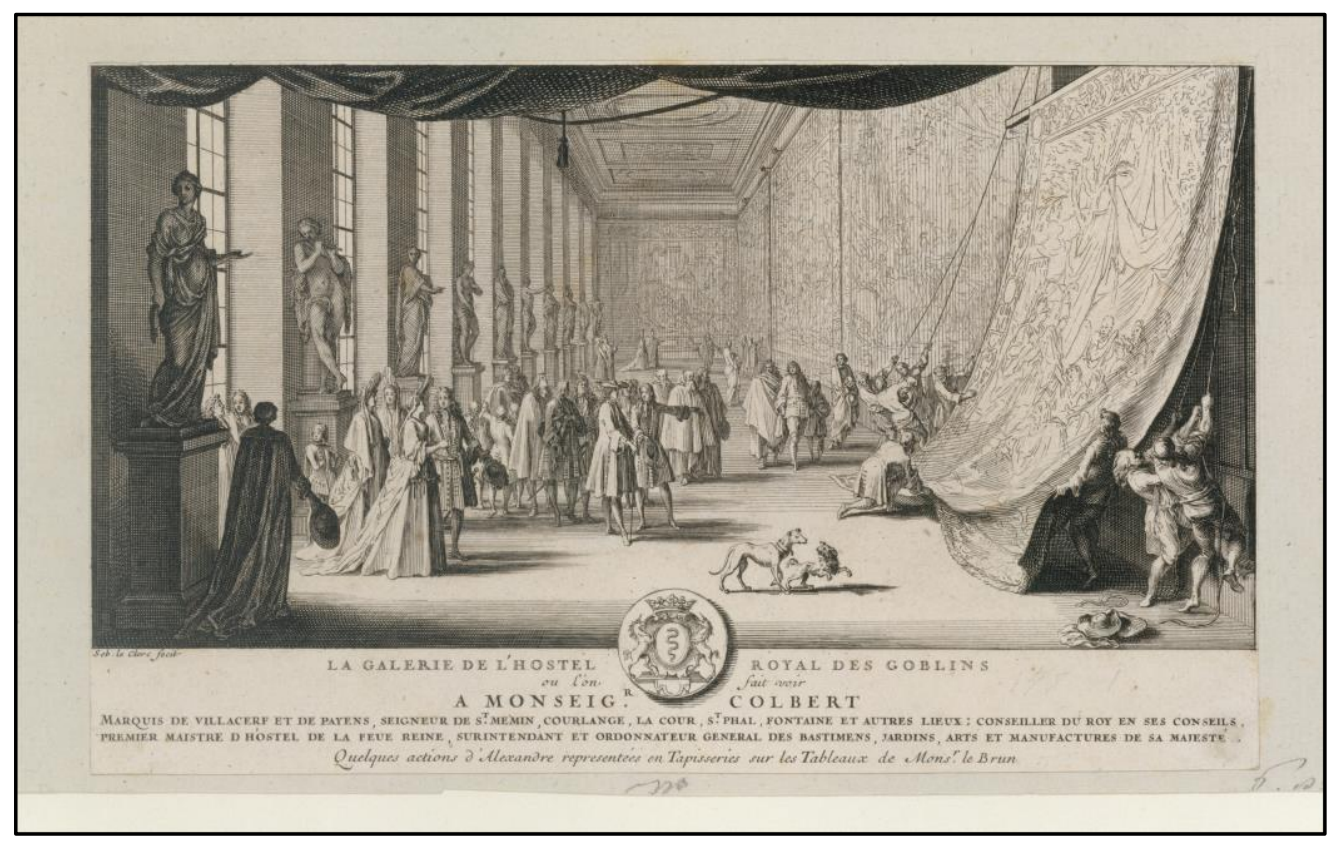

Fig. 3- Sébastien Leclerc, La visita de Colbert de Villacerf a los Gobelinos. 1696, Nueva York, The Metropolitan Museum of Art.

Pero Alejandro y la familia de Darío no solo evoca la magnanimidad del monarca macedónico. También, y eso quiero destacar ahora, su galantería cortesana. Así lo interpretó Baltasar Castiglione en uno de las obras fundamentales del Humanismo renacentista, Il libro del'Cortegiano (Aldo Manucio, Venecia, 1528; traducido al castellano

\footnotetext{
371.

2 Thomas P. Campbell, ed., Hilos de esplendor. Tapices del Barroco (Madrid: Patrimonio Nacional, 2008), 
por Juan Boscán como El Cortesano, 1534), cuando alaba la continencia del rey de Macedonia «con la mujer y hijas hermosísimas de Dario, enemigo y vencido». Igual interpretación hizo Cristina de Suecia del respeto de Alejandro por la mujer del rey persa, en su manuscrito Le grand Alexandre (1675-1680): «esa misma virtud le impidió de igual modo ver a la reina, esposa de Darío, porque era de notable belleza: único rival capaz de provocar su fuga» ${ }^{3}$. Se refiere la reina Cristina al rechazo de Alejandro tras conocer a Estatira a encontrarse cara a cara de nuevo con la que era considerada la mujer más hermosa de Asia, para no sucumbir a su belleza -aceptando en cambio casarse con su hija, también llamada Estatira-. En otro momento Cristina califica a Alejandro de «príncipe galante, que no era ni frío ni insensible pero que deseaba conservar el control sobre sí mismo y entregarse por entero a la gloria».

Castiglione, noble, diplomático y escritor que había residido en las cortes de Milán, Mantua, Urbino y Roma, amigo de Rafael, y nuncio de la Cámara Apostólica de Clemente VII en Toledo, publicó El Cortesano un año antes de morir en esta última ciudad en 1529. En el mismo, y a través de los cuatro libros en que se divide, se esfuerza en describir un caballero nuevo -y una perfecta dama-, versado en las armas, en las letras y en las artes, refinado y elegante, coincidente con el ideal humanista. Para ello va proponiendo a lo largo de las páginas y por medio de un interminable diálogo con personajes de su tiempo -Isabel Gonzaga, Juliano de Medici, Francisco María della Rovere, etcétera- diversos ejemplos históricos que materialicen este modelo, siendo Alejandro de Macedonia uno de los más recurrentes. El método que emplea consiste en recordar anécdotas de su vida que permiten resaltar las cualidades del buen Príncipe tal como éste fue concebido en el Renacimiento. Como por ejemplo, cuando lloró al saber que el firmamento albergaba infinitos mundos y el aún no había conquistado uno; o que guardaba junto a la cabecera de su cama un ejemplar de la Ilíada; o su admiración por Aquiles; o su fascinación por la música.

La referencia admirativa e imitativa a Alejandro el Grande en la obra de Castiglione no es casual, porque la emulación del rey macedonio marcó desde su muerte en el año 323 a.C. y durante dos milenios a generaciones de cazadores de gloria en un proceso sin fin que eclosionó precisamente en el Renacimiento ${ }^{5}$. Es interminable desde la Antigüedad al mundo contemporáneo el número de reyes, militares y estadistas que han tomado como referente de sus propios proyectos políticos a Alejandro y han pretendido emularlo. Cesare Ripa en su Iconologia (Roma, 1593) describe la alegoría de la Emulación, explicándonos, a partir de la Retórica de Aristóteles, el significado de este concepto: el dolor y el estímulo que experimentamos cuando descubrimos en nuestros

\footnotetext{
${ }^{3}$ Margarita Torrione, Alejandro, genio ardiente. El manuscrito de Cristina de Suecia sobre la vida y hechos de Alejandro Magno (Madrid: Antonio Machado Libros, 2011), 151.

${ }^{4}$ Ibídem, 104.

${ }^{5}$ Víctor Mínguez e Inmaculada Rodríguez Moya, Emulating Alexander. Studies on the Visual Legacy of the King of Macedonia from the Renaissance to the Age of Revolution (Leiden: Brill, en prensa).
} 
semejantes algún aspecto honorable del que carecemos pero que también nosotros podríamos alcanzar. Una segunda alegoría, «Emulación, competencia y estímulo para alcanzar la gloria», es descrita portando una palma adornada con cintas como la que se entregaba en la cultura clásica al vencedor, «simbolizando así que la emulación nos estimula para alcanzar las más altas de las glorias, espoleándonos con el deseo de obtener los primeros premios» ${ }^{6}$. El sufrimiento, la angustia y la aspiración a lo más alto caracterizaron pues la emulación alejandrina en el sentido barroco, siendo muy distinta por tanto a una mera imitación. Eso sí, nadie nunca pretendió superar al conquistador macedonio. Tal reto nadie se lo propuso, ni siquiera Julio César o Napoleón. No aparece como propósito en ningún discurso propagandístico, ni siquiera de forma retórica. Como ha descrito con acierto Irene Vallejo, Alejandro competía con los héroes míticos, con el mismísimo Aquiles, al que sin duda superó en hazañas ${ }^{7}$. Nadie podía por tanto competir con él, solo intentar igualarle.

Las lágrimas de César en el templo de Gades dedicado a Hércules-Melqart en el año 69 a.C. cuando, siendo aún tan solo cuestor de la Hispania Ulterior, y ante una estatua de Alejandro recordó que éste, a su edad -treinta y tres años- ya había conquistado el mundo, prueban mejor que ningún otro testimonio la ansiedad provocada por la emulación ${ }^{8}$. Esa escultura se conservó más de mil setecientos años en Cádiz, si creemos a Juan Bautista Suárez de Salazar, que a principios del siglo XVII la menciona y la reproduce por medio de una xilografía en su obra Grandeza y antigüedades de la isla y ciudad de Cádiz. (Cádiz, 1610)' ; y era en Cádiz precisamente y según el mito y las explicaciones de geógrafos romanos como Pomponio Mela (Chorographia I, 5, 27), donde habían estado ubicadas en la Antigüedad las columnas de Hércules que marcaban los límites del mundo conocido -non terrae plus ultra- y que Carlos $\mathrm{V}$ superó cuando sus naves surcaron el Atlántico para conquistar América dejando constancia de la hazaña en su lema Plus Oultre («Mas allá»). Julio César lloraba de impotencia porque no podía emular a Alejandro ${ }^{10}$; Carlos $\mathrm{V}$ no imitaba a Hércules, sino que le superaba yendo más lejos que él. El objetivo de ambos -César y Carlos de Habsburgo- era la conquista del mundo. Y precisamente, el reconocimiento de Alejandro como primer soberano del mundo fue la circunstancia que le convirtió durante siglos en modelo de los reyes y emperadores más ambiciosos.

Pero la imitación de Alejandro en la Edad Moderna ofrecía la dificultad de querer emular a una leyenda, no a un personaje concreto, pues los relatos que circulaban sobre él desde hacía siglos habían producido un arquetipo, un prototipo idealizado muy alejado del hombre real que fue. La más completa recopilación sobre

\footnotetext{
${ }^{6}$ Cesare Ripa, Iconología (Madrid: Akal, 1996), vol. I, 316-320.

7 Irene Vallejo, El infinito en un junco. La invención de los libros en el mundo antiguo (Madrid: Siruela, 2019), 30.

${ }^{8}$ Plutarco, Vida de César, edición de Eduardo Fernández (Madrid: Rialp, 2016), XI; Suetonio, Vida de los doce césares, edición de Mariano Bassols de Climent (Madrid: CSIC, 1996), VII.

${ }^{9}$ Miguel Morán Turina, La memoria de las piedras. Anticuarios, arqueólogos y coleccionistas de antigüedades en la España de los Austrias (Madrid: Centro de Estudios Europa Hispánica, 2010), 158-161.

${ }^{10}$ Peter Green, "Caesar and Alexander: Aemulatio, Imitatio, Comparatio", American Journal of Ancient History 3/1 (1978): 1-26.
} 
fuentes alejandrinas nos la ha proporcionado Robin Lane Fox, que pone al respecto el dedo en la llaga al recordarnos que las únicas referencias originales para conocer al verdadero Alejandro son las de Calístenes, Ptolomeo, Aristóbulo, Nearco y Onesícrito -amigos o servidores del rey macedonio-, pero que éstas no las conocemos directamente, sino a través de citas y referencias de historiadores que vivieron y escribieron ya varios siglos después de la muerte de Alejandro, durante la República y el Imperio Romano ${ }^{11}$. Por su parte, Francisco Javier Gómez Espelosín ha dedicado su último libro sobre Alejandro a abordar precisamente esta problemática historiográfica y establece muy bien las dificultades de conocer a este personaje carismático, poliédrico y polémico: no existen fuentes macedónicas, las fuentes griegas son parciales y sesgadas, la mitificación de Alejandro se inició ya en vida de éste impulsada por él mismo, muchas de las anécdotas que se le atribuyen son inventadas, su vida es novelada, y su hechos reinterpretados desde patrones morales posteriores ${ }^{12}$. Con esta reflexión crítica sobre la dudosa fiabilidad de las fuentes procedentes de la Antigüedad quiero dejar de manifiesto que Alejandro no es solo un referente histórico, sino también un mito cultural que ha crecido y permutado a lo largo del tiempo, y que su éxito en la Edad Moderna tiene también mucho que ver con leyendas y tópicos que oscurecen o confunden al personaje real -Wolfgang Will afirmó acertadamente que la vida de Alejandro nunca conoció el final por seguir escribiéndose hasta nuestros días ${ }^{13}$, pero que para nosotros son sin embargo tan relevantes como las fuentes originales, porque sin ellas no es posible entender las claves iconográficas de Alejandro en este tiempo y su presentación permanente como modelo a imitar.

Ningún otro gobernante ha despertado tanta admiración, fascinación o pasión entre sus colegas como Alejandro a lo largo de la Historia. Fue una contante en la Antigüedad, hasta el punto en que los emperadores romanos Caracalla y Alejandro Severo lo convirtieron en un culto deificando al rey de Macedonia. Esta estrategia fue ya alentada en vida por el propio Alejandro, al vincularse genealógicamente a Aquiles y Heracles, proclamarse faraón e hijo de Amón-Ra, y medirse en logros con Dioniso tras la campaña de la India ${ }^{14}$. Precisamente, la asimilación con Dioniso convirtió al rey de Macedonia en la ideología imperial romana de la época de Trajano y Adriano en el Domitor Orientis («conquistador de Oriente») ${ }^{15}$. También deslumbró durante la larga Edad Media, cuando, aunque fantaseado, el recuerdo de Alejandro fue constante. Y no solo en la Europa cristiana, también en las culturas judía e islámica. Y asimismo sucedió naturalmente en el Renacimiento y en el Neoclasicismo, cuando la mirada de Occidente volvió sobre la cultura clásica grecorromana y puso de nuevo en valor los relatos alejandrinos de Calístenes, Curcio, Plutarco, Diodoro y Arriano.

\footnotetext{
${ }^{11}$ Robin Lane Fox, Alejandro Magno. Conquistador del mundo (Barcelona: Acantilado, 2007), 807-816.

${ }^{12}$ Francisco Javier Gómez Espelosín, En busca de Alejandro. Historia de una obsesión (Alcalá de Henares: Universidad de Alcalá, 2015).

${ }^{13}$ Wolfgang Will, "El mito de Alejandro", en Alejandro Magno. Encuentro con Oriente, ed. Alfried Wieczorek (Madrid: Canal de Isabel II, 2010), 44.

${ }^{14}$ Cristina García García, "La divinización de Alejandro Magno", Revista Estudios 35 (2017): 362-389.

${ }^{15}$ Chiara Frugoni, La fortuna di Alessandro Magno dall'antichità al Medioevo (Firenze: La Nuova Italia, 1978), 7-9.
} 
Otros personajes del mundo antiguo también admirados en la posteridad, como Aníbal, Julio César o Marco Aurelio, quedan muy por detrás en la trascendencia de la imagen artística y literaria de Alejandro. Y eso que no han faltado durante siglos filósofos, teólogos o ilustrados que han criticado el comportamiento de Alejandro durante los últimos años de su reinado por su deriva absolutista en el gobierno de su imperio y por su vida desenfrenada. Pero, con todo, el cocktail que ofrecía el personaje -que detentó los títulos de hegemon de la Liga Corintia, rey de Macedonia y de Asia, y faraón de Egipto- era irresistible: un joven atractivo y valiente, educado por Aristóteles, representado por los mejores artistas de Grecia -como el pintor Apeles y el escultor Lisipo-, que junto a un selecto grupo de compañeros de la aristocracia macedonia, y al frente de un pequeño ejército derrotó al inmenso imperio persa aqueménida tras ganar batallas asombrosas -como Issos, Gaugamela o Hidaspes-, y sin conocer jamás la derrota, viajaría desde el Egipto faraónico a la ignota India, liberando las ciudades griegas de Asia Menor -Éfeso, Halicarnaso, Pérgamo o Mileto-, conquistando ciudades milenarias -Tiro, Gaza, Menfis, Babilonia, Susa, Persépolis o Ecbatana-, y fundando más de medio centenar de nuevas -las alejandrías- en todas partes, expandiendo la cultura helena -la filosofía, el arte, la política, la literatura- por tres continentes y creando una nueva civilización, el mundo helenístico, cuyo limites quedarán delimitados tras su muerte por las siete maravillas de la Antigüedad. Pese a su breve vida transformó en tan solo once años el mundo antiguo.

Fruto de la admiración de sus contemporáneos o de la propia complacencia consigo mismo de Alejandro, la imitatio Alexandri arrancó ya en vida del conquistador ${ }^{16}$. Y desde luego siguió creciendo durante siglos con distinta intensidad hasta el presente más actual. Sus sorprendentes e incuestionables conquistas lo convirtieron en referente de estrategas y emperadores ya en la Antigüedad ${ }^{17}$, siendo modelo de los más grandes estadistas y militares de la misma como Pirro, Escipión el Africano, Pompeyo - magnus-, Craso, Julio César -philaléxandros-, Marco Antonio, Augusto, Trajano -kosmokrátor-, Adriano, Caracalla -philalexandrótatos y magnus-, Alejandro Severo, Constantino o Juliano $^{18}$. También es cierto que ya en la Antigüedad fue objeto de numerosas críticas, procedentes de autores como Cicerón, Livio, Séneca o Lucano, y ya he explicado las razones: su ambiguo comportamiento moral y al uso desmedido con el que ejerció el poder. Francisco Rodríguez fija el inició de su enfrentamiento con los filósofos en el año 327, cuando Alejandro mandó detener a su historiador Calístenes acusado de conspirar contra él -la conjura de los pajes- tras haber discrepado ambos con respecto al uso del ceremonial persa -especialmente el saludo de la proskynesis. Desde ese

\footnotetext{
16 Paul Goukowsky, Essai sur les origines du mythe d'Alexandre (336-270 a.C.). Vol. I: Les origines politiques (Nancy: Université de Nancy, 1978); y Paul Goukowsky, Essai sur les origines du mythe d'Alexandre (336270 a.C.). Vol. II: Alexandre et Dionysos (Nancy: Université de Nancy, 1981).

${ }^{17}$ Glenn Barnett, Emulating Alexander: How Alexander the Great's Legacy Fuelled Rome's Wars with Persia (Gran Bretaña: Pen \& Sword Books, 2017).

${ }^{18}$ Francisco Javier Gómez Espelosín desgrana cada uno de estos casos romanos y otros más en Gómez Espelosín, En busca, 303-327. Véase también Salvatore Alessandri, "L’Imitatio Alexandri augustea e i rapporti fra Orazio e Curzio Rufo", Studi Classici e Orientali 18 (1969): 194-210.
} 
momento y durante los siglos siguientes se granjeó las críticas de peripatéticos, estoicos y cínicos - como Diógenes ${ }^{19}$.

En los inicios del siglo XVII encontramos dos referencias alejandrinas muy interesantes en la literatura barroca hispana. Sebastián de Covarrubias Horozco, en su Tesoro de la Lengua castellana o española (Madrid, 1611), sintetiza la valoración que del rey macedónico se tenía en el Siglo de Oro de la cultura española y europea: «muchos hubo deste nombre, pero absolutamente se toma por Alejandro Magno, hijo de Filipo, rey de Macedonia, que señoreó la mayor parte del mundo y todo él se le hizo poco y al fin se vino a contentar con siete pies de sepultura» ${ }^{20}$. Al margen de este último pensamiento ya barroco, las palabras de Covarrubias destilan admiración sin límites por el personaje, y prosigue destacando que Alejandro fue apasionado de Homero, envidioso de Aquiles, y retratado por Apeles, Lisipo y Pirgoletes. Concluye finalmente que su nombre es sinónimo de liberal y generoso.

La segunda referencia alejandrina es un manuscrito escrito en las primeras décadas del Seiscientos por el sacerdote e historiador conquense Baltasar Porreño (1569-1639) y lleva por título Museo de los Reyes sabios que an tenido las Naciones del Orbe, y los libros que ellos y los emperadores y infantes an escrito y sacado a luz. (manuscrito 2297 de la Biblioteca Nacional, Madrid). Porreño sostiene que todos los reyes y emperadores famosos por su buen gobierno se rodearon de sabios y estudiosos: «la sabiduría es tan necesaria al Príncipe como el alma al cuerpo; y aquellas Repúblicas son bienaventuradas, que o las gobiernan Philosophos, o por buena suerte los que tienen el mando dellas saben philosophar» ${ }^{21}$. Y tras mencionar al emperador Antonino Pío inmediatamente se refiere a Filipo de Macedonia, que impulsó a su hijo Alejandro al estudio de las letras y le asignó como maestro a Aristóteles. Después de un itinerario sapiencial introductorio a través de Salomón, Moisés, emperadores romanos, reyes magos y el propio Alejandro, dedica una serie de pequeños capítulos biográficos a los monarcas que él considera especialmente sabios, entre otros Adriano, Alejandro Severo, Constantino, Carlos V, Julio Cesar, Marco Aurelio, Maximiliano I, Octavio Augusto, Trajano, Vespasiano, Tito, David, Salomón, Jaime I, Carlomagno, San Luis, Ciro, Ptolomeo o Solimán el Magnífico. El capítulo 12 lo dedica a los «Reyes de Macedonia amigos de letras, y honradores de sabios», destacando de Filipo el tiempo que dedicó a las letras y la elección de Aristóteles como preceptor de su hijo; y de Alejandro recuerda como atribuyó su conquista del mundo más a las enseñanzas del filósofo que a la riqueza heredada de su padre, y como fue sensible a la compañía de Pindaro, Jenócrates, Onesicrito, Diógenes, Anaxarco y otros sabios de su tiempo de los que gustó rodearse.

\footnotetext{
${ }^{19}$ Francisco Rodríguez Adrados, "Las imágenes de Alejandro", en Alejandro Magno. Hombre y mito, eds. Jaime Alvar y José María Blázquez (Madrid: Actas, 2000), 16.

${ }^{20}$ Sebastián de Covarrubias Horozco, Tesoro de la lengua castellana o española. Edición integral e ilustrada de Ignacio Arellano y Rafael Zafra (Pamplona: Universidad de Navarra y Editorial Iberoamericana, 2006), 102.

${ }^{21}$ BNE, Mss. 2297: Baltasar Porreño, Museo de los Reyes sabios que an tenido las Naciones del Orbe, y los libros que ellos y los emperadores y infantes an escrito y sacado a luz, 1.
} 
Precisamente, y para alabar la sólida formación intelectual de Alejandro, Castiglione recuerda que fue discípulo de Aristóteles, que le formó tanto en ciencias naturales, como en las virtudes del alma, como en la filosofía moral, «infinitos hombres fueron por causa destas leyes reduzidos de la vida saluaje y bestial à la humana, y estas cosas que Alexandre hizo todas se las hizo hacer Aristoteles siendo buen Cortesano» ${ }^{22}$. Para evidenciar su mecenazgo artístico, se destaca su afecto por Apeles, al que llegó a entregar su concubina Campaspe de la que el pintor se había enamorado tras emplearla como modelo, y se recuerda que éste es un ejemplo entre mil que evidencian el amor del rey por el artista, al que llegó a conceder la exclusividad a la hora de representar su figura. Para manifestar su grandeza y magnificencia, se recuerdan las grandes obras que emprendió, como la fundación de numerosas ciudades -como Alejandría en Egipto o Bucefalia en la India-, y su colosal proyecto escultórico para el monte Athos: «estas tales cosas pienso yo señor Otauian que son las que propriamente conuienen a vn excelente y verdadero Principe, y las que le hazen en la paz y en la guerra señalado por todo el mundo» ${ }^{23}$.

Integrar a Alejandro en la cultura cortesana del Renacimiento no era en cualquier caso complicado puesto que las distintas versiones del Roman d'Alexandre que circulaban por Europa desde el siglo XII ya habían familiarizado a la sociedad bajo medieval con la imagen caballeresca del rey de Macedonia. Las miniaturas que ilustran alguna de estas versiones muestran junto a las gestas guerreras diversas escenas palatinas entre las que destacan para nuestro propósito las vinculadas al banquete de los Votos del Faisán. Recordemos que éste tuvo lugar el 17 de febrero de 1454, cuando aún no había transcurrido un año de la caída de Constantinopla. En un escenario decorado fastuosamente para la ocasión, el duque Felipe III de Borgoña y un gran número de caballeros emitieron el voto de cruzada ${ }^{24}$. Las miniaturas realizadas por el pintor Guillaume Wyelant, para la L'Histoire du bon roi Alexandre muestran escenas del deslumbrante banquete, en cuya mesa luce la mejor orfebrería y vajilla, y en torno a ella a comensales y sirvientes con más copas y jarras en las manos. La justificación de que un relato visual de la vida de Alejandro mostrara escenas del festejo borgoñón residía en que la tradición atribuía al rey de Macedonia haber introducido el faisán en Europa. Por ello, y en el transcurso de una complicada representación que incluía referencias a Jasón -también se atribuía a este héroe mítico traer esta ave a Grecia-, al Vellocino de Oro y al auxilio a Jerusalén, el rey de Armas Toisón de Oro entraba en determinado momento con un faisán vivo ornamentado con un rico collar de oro, perlas y pedrería, que simbolizaba Oriente y el río Phasis de la Cólquide, es decir, Tierra Santa. El rey de armas instaba entonces al duque a formular un voto, siguiendo una

\footnotetext{
22 Baltasar Castiglione, El Cortesano tradvzido por Boscan en nvestro vulgar Casellano, nuenamente aogra corregido (Amberes: Philippo Nucio, 1574), 228.

${ }^{23}$ Castiglione, El Cortesano, 219.

${ }^{24}$ Marie Thérèse Caron, "El Banquete de los votos del Faisán y la fiesta de corte borgoñona”, en El legado de Borgoña. Fiesta y Ceremonia Cortesana en la Europa de los Austrias (1454-1648), eds. Krista de Jonge, Bernardo J. García García, y A. Esteban Estríngana (Madrid: Marcial Pons y Fundación Carlos de Amberes, 2010), 21-34.
} 
costumbre caballeresca de comprometerse ante un pavo real, un faisán u otra ave noble que era traída por una doncella ${ }^{25}$.

$\mathrm{Al}$ igual que los duques de Borgoña recurrieron al ave en el siglo XV para vincularse a la leyenda de Alejandro, la emergente casa de Habsburgo hizo lo propio en la centuria siguiente: la pintura anónima Habsburger Pfau, o Pavo Real de los Habsburgo (1555, Castillo de Ambras, Innsbruck), realizada para el nuevo emperador Fernando I cuando sucedió a su hermano Carlos en el trono, es quizá la representación visual más potente de las muchas que se realizaron para manifestar la voluntad hegemónica de esta familia. El ave despliega sobre su cola un sinfín de blasones de los dominios territoriales de este linaje en el año de la abdicación del emperador Carlos $\mathrm{V}$ y de la división del Imperio habsbúrgico entre su hermano Fernando y su hijo Felipe. Otros ocho cuartelados reales se reparten por el marco. Además, el ave se apoya en un cojín en el que contemplamos las insignias del poder -el collar, el cetro, la espada y el collar del Toisón- y aparece enmarcada por dos nuevos escudos y las columnas hercúleas de la divisa carolina: el insaciable Plus Ultra que parece no conocer límites una vez superados los del mundo antiguo. Numerosas cartelas y una filacteria con el lema Non nobis domine non nobis sed nomini tvo da gloriam. Psal. CXIIII («Nada para nosotros señor, nada para nosotros, sino para la gloria de tu nombre») -que justifica y sacraliza la ambición política- completan el discurso visual que representan en total ochenta y un escudos $^{26}$. Es importante advertir que, en realidad, y pese a la denominación con la que es conocida habitualmente, el ave no es un pavo real, sino un faisán azul, y que por medio del recurso a esta ave alejandrina los Habsburgo manifestaban su deseo de alcanzar, como el rey de Macedonia, la dominación universal.

En cualquier caso, fueron muchos los príncipes de Europa que buscaron en los siglos XVI y XVII emparentarse simbólicamente con Alejandro. Y es por ello que abundan las salas alejandrinas en los palacios del Renacimiento y del Barroco. Recordemos por ejemplo la decoración pictórica de la Sala Paolina del Castillo de Sant'Angelo en Roma, promovida por el papa Pablo III, y realizada por diversos pintores encabezados por Perino de Vaga entre 1545 y 1547. El protagonismo de Alejandro en la misma -hasta seis escenas- se debe a la coincidencia onomástica entre el pontífice -Alessandro Farnese- y el rey de Macedonia. Fijémonos ahora en la también romana Villa de La Farnesina, encargada por el banquero sienés Agostino Chigi al arquitecto Baldassare Peruzzi en la margen derecha del Tíber (1506-1510), y decorada al fresco por el propio Peruzzi además de Rafael, Sebastiano del Piombo y Giovanni Antonio Bazzi El Sodoma (1510-1519). Este último fue el artífice de los frescos de la llamada Sala de Alejandro o dormitorio principal. Preside el conjunto, en consonancia como el uso de la cámara, la Boda de Alejandro y Roxana-estableciendo un paralelismo con los propietarios de la villa, Agostino y su esposa Francesca-, y recreada a partir de la descripción de Luciano de Samósata de un original perdido realizado por el

${ }^{25}$ Francesc Massip, "El toisón de oro en escena: espectáculo e imagen al servicio de la casa de Borgoña," en A la búsqueda del Toisón de Oro. La Europa de los Príncipes. La Europa de las ciudades, eds. Eduard Mira y An Delva (Valencia: Generalitat Valenciana, 2007), vol. I, 213-223.

${ }^{26}$ Víctor Mínguez e Inmaculada Rodríguez Moya, El tiempo de los Habsburgo. La construcción artística de un linaje imperial en el Renacimiento (Madrid: Marcial Pons, 2020), 26-28. 
pintor Aezión. Le acompañan otras tres escenas: Alejandro domando a Bucéfalo, Alejandro en la batalla y La familia de Darío ante Alejandro.

Inicialmente Alejandro gobernó su reino macedonio desde su capital, Pella. Y tras vencer definitivamente a Darío III estableció la capital de su gran imperio asiático en Babilonia. Pero su reinado transcurrió en un viaje incesante hacia el Oriente al frente de su ejército, un periplo interminable y sin retorno, y su corte estuvo en cada momento allí donde él residía, ya fuera una ciudad conquistada, liberada, fundada o un campamento militar -según Plutarco, Alejandro fundó setenta ciudades, y la lista de las que conquistó es mucho mayor-. La itinerancia permanente de la corte de Alejandro es otro aspecto que también permite vincular su figura a los Habsburgo hispanos: como duques de Borgoña éstos gobernaron Flandes desde Bruselas, pero una vez multiplicaron sus dominios gracias a las coronas de Castilla y Aragón y sus múltiples posesiones americanas e italianas, desplazaron su centro de decisión hacia la Península Ibérica: si Carlos $\mathrm{V}$ aún fue un emperador itinerante en viaje permanentemente, Felipe II, aunque también viajero, estableció una corte estable en la villa de Madrid.

Quiero reparar a continuación en cuatro episodios de la vida de Alejandro que transcurren entre amigos, cortesanos, damas y funcionarios: tres en espacios palatinos de las ciudades de Tarso, Persépolis y Samarcanda, y otro que acontece en los caminos de Mesopotamia. La iconografía de estos momentos alejandrinos adquiere un perfil dramático al ser representados por el arte moderno, visualizando enfermedad, destrucción, crimen y muerte. Pero también evocan valor, remordimiento y amor. Algunas de estas escenas palatinas recrean los momentos más controvertidos de Alejandro, como si el desenfreno que le criticaron tantos escritores de la Edad Moderna encontrara su escenario idóneo en los ambientes cortesanos mucho más que en los épicos y ennoblecedores campos de batalla -ciertamente estos últimos estaban concebidos como espacios de virtud desde la perspectiva de la mentalidad barroca o ilustrada-, un desenfreno que se fue acentuando a lo largo de su vida conforme se dejó seducir por Asia. El primero de ellos se refiere a la enfermedad que Alejandro sufrió en Tarso y su temeraria confianza en el médico en el que depositó su recuperación. El segundo a la destrucción de Persépolis por decisión de Alejandro o instigado por una mujer. El tercero al famoso banquete en Samarcanda en el que Alejandro, preso de ira, dio muerte a su amigo Clito. Y el cuarto a la muerte de Estatira y al homenaje que Alejandro rindió a su cadáver, permitiéndose admirar finalmente su belleza. En cada caso analizaremos una pintura singular que recreó el acontecimiento en cuestión en la Edad Moderna.

La primera pintura corresponde a Hans Wertinger, el suabo (h. 14651470/1533), y es Alejandro Magno enfermo y su físico, (1517, Galería Nacional de Praga, Palacio Sternberk, Praga) (Fig. 4). Wertinger fue un pintor alemán volcado primero en la realización de retablos religiosos y, una vez fue nombrado pintor de la corte del duque Luis X de Baviera en 1518, en el género del retrato -el Museo del Prado custodia uno del emperador Federico III-. Veamos primero qué episodio recoge esta pintura y luego analizaremos la composición. En el verano del 333 a.C., y tras cruzar las Puertas Cilicias y liberar la ciudad de Tarso, Alejandro enfermó: el cambio de temperatura entre las colinas y el valle le provocó un resfriado que se complicó al bañarse en las frías aguas del río Cidno -curiosamente el mismo en el que quince siglos después se 
ahogaría el emperador germánico Barbarroja en el contexto de la Tercera Cruzada-. Las fiebres y escalofríos hicieron temer a sus médicos lo peor, pero el griego Filipo de Arcarnania propuso, con el consentimiento del rey, administrarle un purgante. Sin embargo, el general Parmenión intervino por medio de una carta avisando de que Darío había sobornado a Filipo para que le diera muerte. Alejandro, mostrando su confianza en el médico al que conocía desde la infancia, bebió la medicina que éste le suministró al tiempo que le entregaba la carta. Poco después sanó, aunque la convalecencia aún duró semanas ${ }^{27}$.

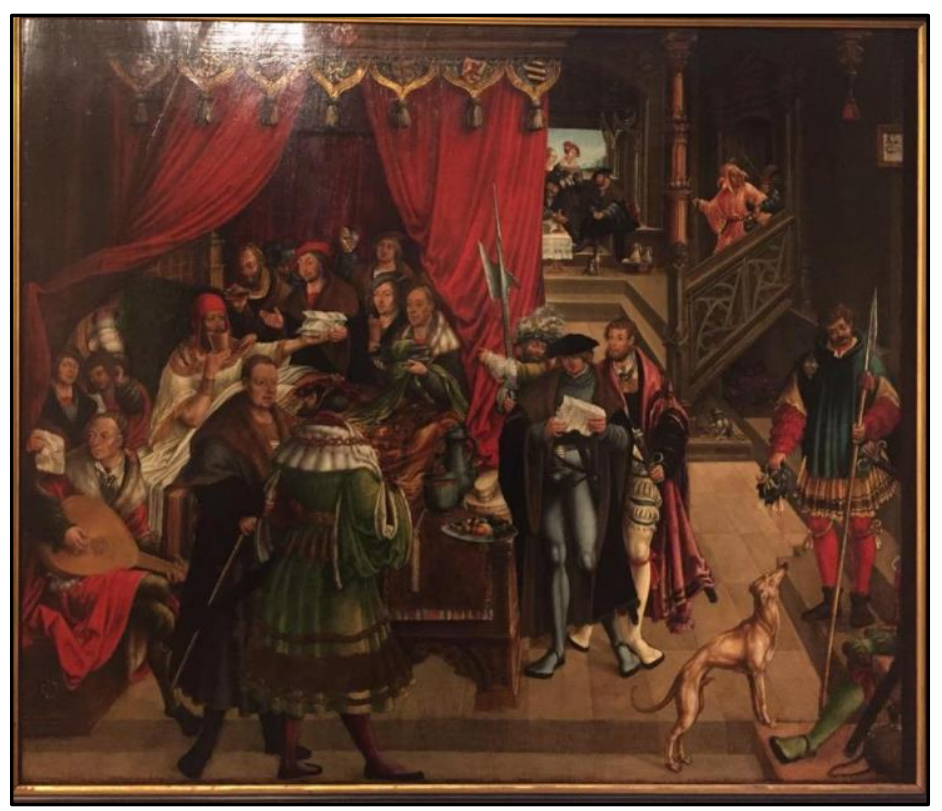

Fig. 4 -Hans Wertinger, Alejandro Magno enfermo y su fisico. 1517, Praga, Galería Nacional de Praga, Palacio Sternberk.

En la pintura de Wertinger contemplamos a Alejandro en su cama, bajo un gran dosel decorado con escudos heráldicos y en una habitación palaciega repleta de personajes trazada en perspectiva lineal. Rodean al rey de Macedonia cortesanos, músicos, soldados, bufones y sirvientes. Alejandro se dispone a beber la copa al tiempo que entrega la misiva acusatoria al médico. A los pies de la cama y vestido con armadura Parmenión se aproxima portando la carta en sus manos en una escena previa. La composición acumula tantos personajes y episodios secundarios -como es habitual en la pintura norteña alejada de los modelos italianos- que el dramatismo de la escena se diluye, y el conflicto que atenaza a Alejandro entre las dos virtudes principescas -

\footnotetext{
${ }^{27}$ Lane, Alejandro, 260-264.
} 
confianza y prudencia- se convierte en un sereno ceremonial cortesano en el que nada parece advertirnos del riesgo que acepta correr el rey de Macedonia.

Cristina de Suecia, asimismo reina y en un probable ejercicio inconsciente de empatía, calificó de imprudente a Alejandro por confiar ciegamente en el médico: «podía creer que le era fiel y suponerlo incorruptible sin someterse a una experiencia harto peligrosa» ${ }^{28}$. Hay que dar un salto de tres siglos para encontrar otra representación de este episodio: a finales del siglo XIX, el pintor ruso-polaco Henryk Siemiradzki (1843-1902), miembro de la Academia Imperial de las Artes de San Petersburgo y de otras diversas academias europeas, volvió a recrearlo, ya en un estilo decimonónico historicista y neoclásico, en su obra Alejandro Magno y el médico Filipo de Arcarnania (1870, National Arts Museum of the Republic of Belarus, Minsk); en esta nueva pintura contemplamos de nuevo el instante en que Alejandro se dispone a beber mientras el médico lee los cargos contra él, en una habitación tapizada en la que destacan las armas del rey depositadas en el sillón y la mesa, y el estupor de dos testigos que contemplan este instante de gran intensidad psicológica (Fig. 5).

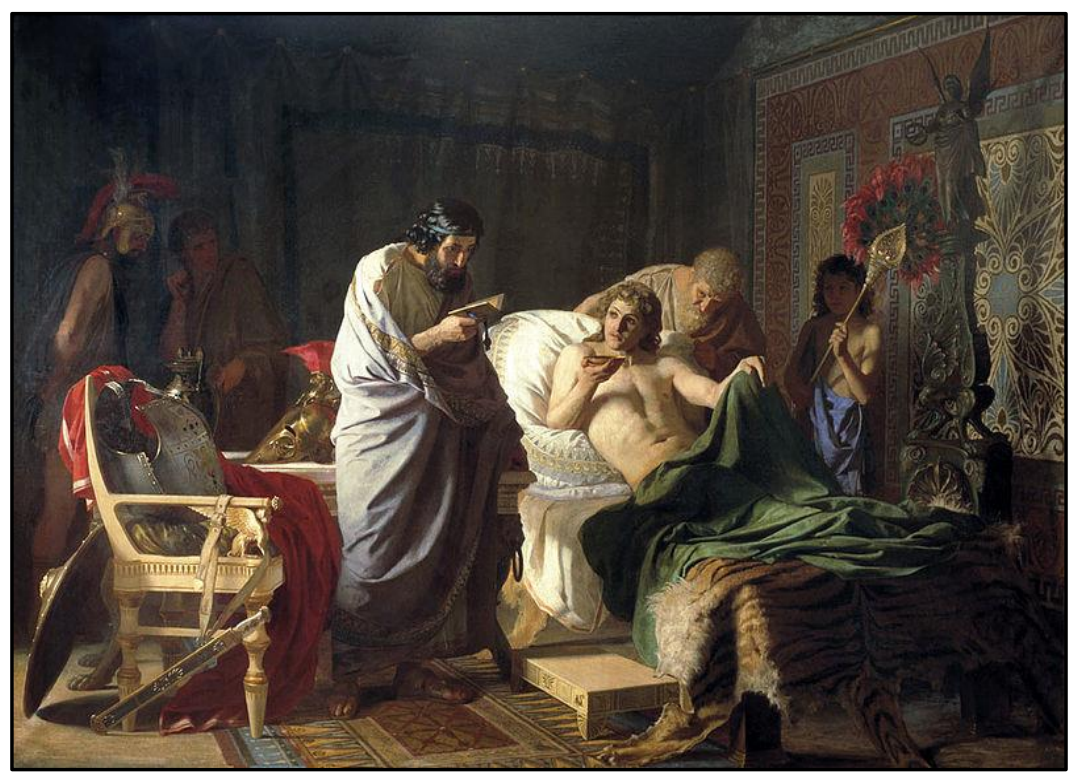

Fig. 5- Henryk Siemiradzki, Alejandro Magno y el médico Filipo de Arcarnania. 1870, Minsk, National Arts Museum of the Republic of Belarus.

${ }^{28}$ Torrione, Alejandro, 104-110. 
La segunda pintura que muestra un episodio palatino de Alejandro corresponde al pintor inglés Joshua Reynolds (1723-1792), el gran retratista de la corte de Jorge III y primer presidente de la Royal Academy, y se conoce como Thais de Atenas con antorcha (1781, Waddesdon Manor, Inglaterra) (Fig. 6). Aunque en ella no aparece Alejandro evoca el suceso más controvertido probablemente de su intensa vida: el incendio de los palacios de Persépolis a finales de la primavera de 330 a.C. Previamente Alejandro se había apoderado del tesoro real y luego consintió en que sus soldados saquearan sin piedad la ciudad. Una tradición que se remonta a Ptolomeo atribuye el incendio al propio Alejandro, en venganza por la destrucción de los templos de la Acrópolis de Atenas en el 480 a.C. a manos de los persas de Jerjes I cuya corte residía precisamente en Persépolis; otra tradición atribuye la catástrofe a Thais, una cortesana ateniense que en medio de un banquete empujó a un embriagado Alejandro y en pleno frenesí dionisiaco a arrojar teas encendidas a la Sala de las Cien Columnas de Jerjes ${ }^{29}$.

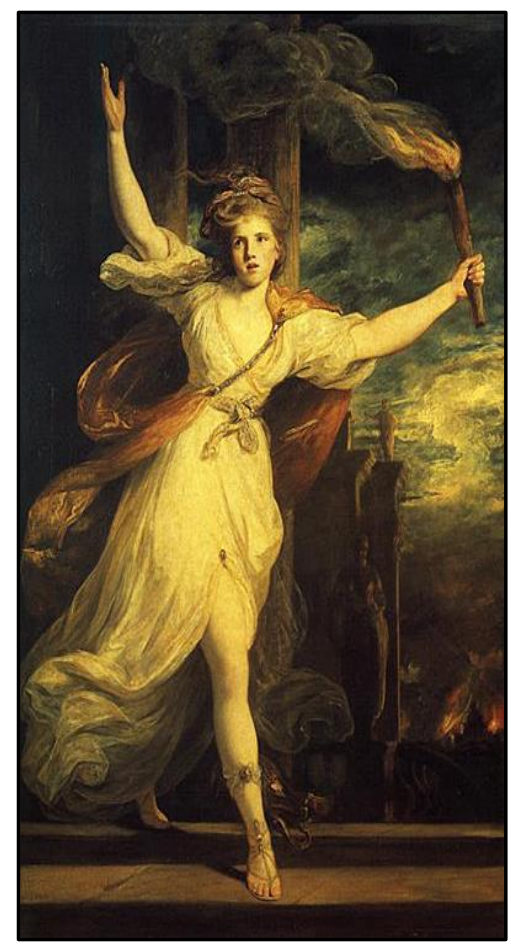

Fig. 6- Joshua Reynolds, Thais de Atenas con antorcha. 1781, Inglaterra, Waddesdon Manor.

${ }^{29}$ Robin Lane apunta que Thais pudo ser la amante de Ptolomeo, y de ahí que éste silenciara su participación en el incendio. Véase Lane, Alejandro, 415-426. 
El retrato de Thais pintado por Reynolds corresponde a la modelo Emily Warren, y la inspiración de la obra, más allá de las fuentes clásicas, es probable que tuviera un origen poético musical. Recordemos que Georg Friedrich Haendel había convertido en 1736 en ópera u oratorio la oda escrita por el poeta John Dryden, El festín de Alejandro o el poder de la música (1697), y la había estrenado en el Convent Garden. Es muy probable que, bien los versos de Dryden, bien la composición de Haendel, llevaran a Reynolds a concebir y ejecutar esta pintura dramática y fantástica, que presagia en su concreción pesadillas ya decimonónicas. Al respecto de este controvertido episodio de la vida de Alejandro Cristina de Suecia no halla justificación: «el hecho de haber incendiado de manera brutal el palacio más bello y la más bella ciudad de Asia, inducido por una hetaira, merece sobradamente la vergüenza y el arrepentimiento que manifestará por ello» ${ }^{30}$.

La tercera pintura de ambientación cortesana que quiero analizar fue realizada por el dibujante, pintor y arquitecto holandés Daniël de Blieck (h. 1610-1673), especializado por su doble formación en pintar interiores arquitectónicos, fundamentalmente de iglesias, reales e imaginarias. En 1663 pintó un cuadro representando a Alejandro matando a Clito el Negro (Ferens Art Gallery, Hull, Inglaterra) que, aunque no deja de ser una excusa para recrear imaginativamente un palacio de la Antigüedad, representa el momento en que el rey de Macedonia, iracundo y embriagado, da muerte a uno de sus compañeros más fieles cuando éste se atreve a hablarle con sinceridad (Fig. 7). Sucedió en Samarcanda en el año 328 a.C., y la víctima fue Clito, hiparca de la caballería de los Compañeros. Como en Persépolis, de nuevo un banquete cortesano en uno de los palacios locales fue el escenario del drama, y la abundancia de vino el detonante. Ante las supuestas provocaciones de Clito Alejandro lo atravesó con una lanza. Inmediatamente éste se horrorizó por lo sucedido, y mortificado intentó incluso suicidarse ${ }^{31}$.

\footnotetext{
30 Torrione, Alejandro, 131-133.

${ }^{31}$ Lane, Alejandro, 495-513.
} 


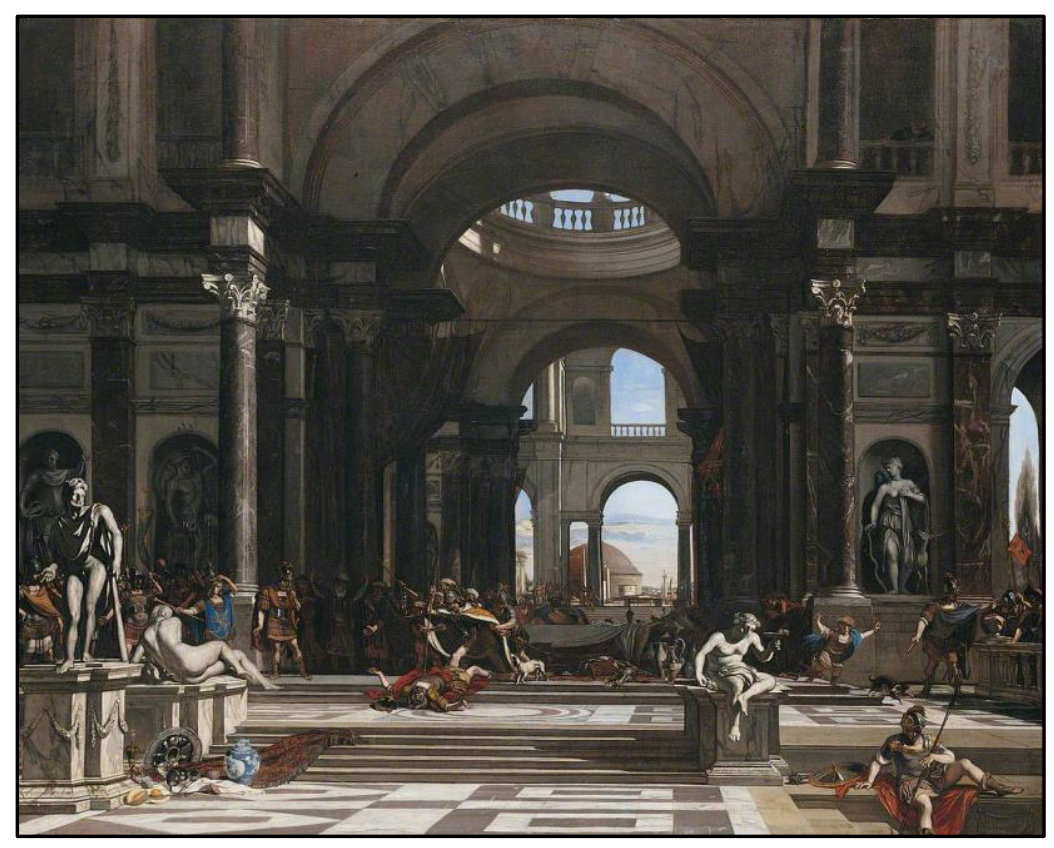

Fig. 7- Daniël de Blieck, Alejandro matando a Clito el Negro. 1663, Hull, Inglaterra, Ferens Art Gallery.

La pintura de historia de Blieck no deja de resultar sorprendente en la escuela holandesa, más volcada en asuntos mitológicos y de género. No obstante, lo cierto es que fueron frecuentes los caprichos arquitectónicos alejandrinos, preferentemente de las escuelas francesa e italiana, que ya en el siglo de la Ilustración aprovechan anécdotas del rey de Macedonia -preferentemente la visita de Alejandro a la tumba de Aquiles en Troya- para realizar fantasías escenográficas meramente decorativas, aunque reveladoras de la popularidad intemporal del rey de Macedonia. Esta pintura de Daniël de Blieck entraría en esta categoría, pero con dos aspectos a tener en cuenta: es muy temprana con respecto a muchas de estas otras pinturas, y selecciona un episodio dramático nada anecdótico, pues muestra un crimen cometido por Alejandro. Y todavía otra particularidad: es una de las mejores recreaciones arquitectónicas del género de las vedutta historicistas. La configuración de un gran espacio abovedado interior, articulado con órdenes clásicos y relativamente diáfano, así como el papel determinante que desempeña en su decoración y significado la estatuaria clásica -con Hércules, Venus y Baco en primer término, y Diana, Apolo y Neptuno en las hornacinas del fondo- recuerda inevitablemente La Academia de Atenas pintada por Rafael en la Estancia de la Signatura (1510-1512, Palacio Apostólico, Vaticano), donde 
por cierto, también aparece representado Alejandro, acompañando a Jenofonte y Sócrates.

Bajo la gigantesca arquitectura palatina se desarrolla la tragedia: ante el espanto de los numerosos comensales -soldados macedonios, personajes orientales, heraldos y criados-, y entre perros agitados y objetos esparcidos por el suelo, Alejandro, al que vanamente intentan detener algunos de sus compañeros, clava una lanza a Clito, caído ya en el suelo. Sobre este momento dramático de la vida de Alejandro, su gran defensora, la reina Cristina, le quita relevancia: «no fue más que una desgracia, puesto que su intención no era matarle; pero el torcido destino de Clito, o por mejor decir su impertinencia, le valió la justa ira de Alejandro y le forzó a castigarle (...) estemos seguros de que pocos príncipes habrían soportado tanto tiempo aquella prueba de paciencia». Y, en cambio, sorprendentemente censura a Alejandro «su inmoderado arrepentimiento por haber obrado mal. Bueno es arrepentirse de una mala conducta, pero llegar hasta la desesperación era mostrar demasiado orgullo e ignorancia» ${ }^{32}$.

La cuarta y última pintura que quiero destacar fue realizada por el pintor francés Louis Jean François Lagrenée (1725-1805). Lleva por título La muerte de la mujer de Darío (1785, Musée du Louvre), y la ejecutó obedeciendo a un encargo de Luis XVI realizado en 1784 (Fig. 8). Cuando Lagrenée pintó esta composición era director de la Academia de Francia en Roma -ya antes había sido director de la Academia de San Petersburgo-. Su obra se enmarca en el estilo rococó pero evolucionado hacia un elegante clasicismo. Esta escena, que transcurre en un exterior diurno porque en ese momento la corte alejandrina transita por los caminos de Asia, muestra la muerte de Estatira, esposa ya citada del rey persa Darío. En la composición Alejandro y Hefestion han descendido de sus caballos y rinden homenaje al cadáver de la reina. Como antes he explicado, Alejandro había estado evitando ver a Estatira desde que la conoció en Iso en noviembre del año 333 a.C., para evitar enamorarse de ella, puesto que su hermosura era legendaria. Finalmente, cuando ella muere dos años después en el 331 a.C., en la ruta hacia Babilonia, el rey de Macedonia se atreve ya a admirar serenamente su belleza.

\footnotetext{
32 Torrione, Alejandro, 112-120.
} 


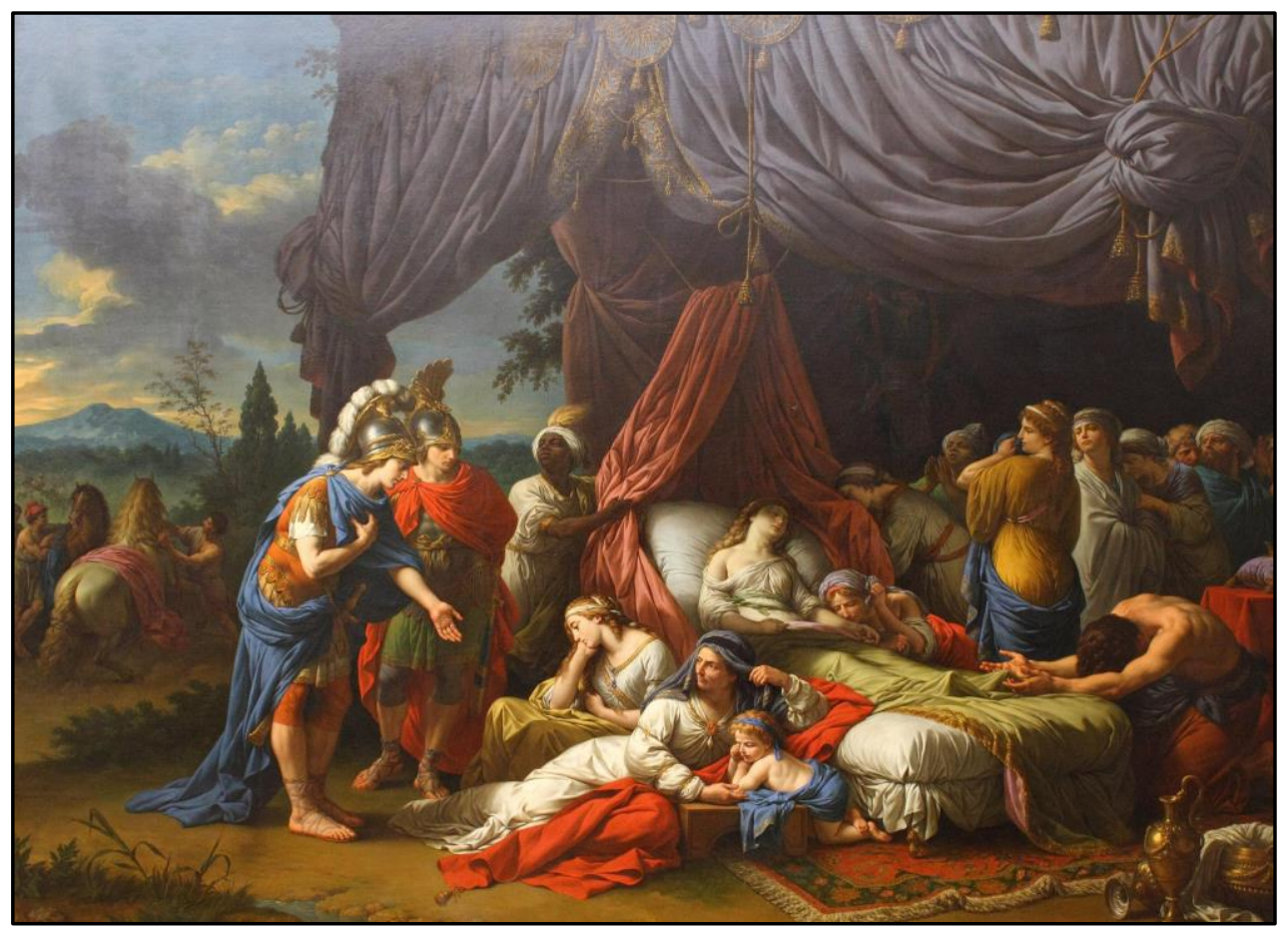

Fig. 8- Louis Jean François Lagrenée, La muerte de la mujer de Darío. 1785, París, Musée du Louvre.

La pintura de Lagrenée forma un díptico con la de Le Brun que me sirvió para iniciar este texto, cerrando un círculo narrativo. Lagrenée admiraba a los pintores de Luis XIV como Le Brun, y las similitudes compositivas entre ambos lienzos son evidentes: la indumentaria y gesticulación de los dos jóvenes macedonios situados a la izquierda, la gran tienda o dosel, y la distribución escalonada de las figuras femeninas y los sirvientes a la derecha son coincidentes. Y temáticamente se corresponden totalmente, pues muestran el primer encuentro entre Alejandro y Estatira, cuando el conquistador descubre la belleza de ésta y decide evitarla; y el segundo y definitivo, transcurrido dos años después, cuando la contempla con admiración y ya sin peligro.

Estas cuatro escenas alejandrinas que hemos visualizado no fueron frecuentes en la pintura cortesana moderna. Los artistas del Renacimiento, del Barroco y académicos se centraron en las recreaciones de las batallas asiáticas de Alejandro, en episodios heroicos de su interminable periplo como su visita a Troya o el corte del nudo Gordiano, o en anécdotas ejemplares de la vida del rey de Macedonia, como su encuentro con Diógenes -tema éste representado por artistas como Pierre Puget, Sebastián Ricci, Giambattista Tiépolo o Francesco Fontebasso- su visita al templo de Jerusalén, o la fundación de Alejandría. La multitud de escenas diversas, históricas y fantásticas que fueron recogidas 
en los libros de miniaturas medievales sobre $L a$ novela de Alejandro se redujeron considerablemente durante la Edad Moderna. Al convertirse Alejandro en modelo y espejo de los reyes del Antiguo Régimen, se omitieron conscientemente en la mayoría de los programas palaciegos los episodios más controvertidos del conquistador. Pero no estuvieron ausentes de los ensayos manuscritos o publicados, como demuestra el discurso de Cristina de Suecia. Por eso el interés de estas pinturas a la hora de reconstruir la recepción de Alejandro en la modernidad. Su singularidad en la densa vida de las imágenes alejandrinas es el mejor testimonio de la polémica que estos episodios suponían en la construcción moderna del mito del rey de Macedonia. Su limitada fortuna iconográfica parece probar que la vida cortesana sentaba mal a la leyenda de Alejandro. 


\section{REFERENCIAS BIBLIOGRÁFICAS}

Alessandri, Salvatore, "L'Imitatio Alexandri augustea e i rapporti fra Orazio e Curzio Rufo", Studi Classici e Orientali 18 (1969): 194-210.

Barnett, Glenn, Emulating Alexander: How Alexander the Great's Legacy Fuelled Rome's Wars with Persia (Gran Bretaña: Pen \& Sword Books, 2017).

Campbell, Thomas P., ed., Hilos de esplendor. Tapices del Barroco (Madrid: Patrimonio Nacional, 2008).

Caron, Marie Thérèse, "El Banquete de los votos del Faisán y la fiesta de corte borgoñona," en El legado de Borgoña. Fiesta y Ceremonia Cortesana en la Europa de los Austrias (1454-1648), eds. Krista de Jonge, Bernardo J. García García, y A. Esteban Estríngana (Madrid: Marcial Pons y Fundación Carlos de Amberes, 2010).

Castiglione, Baltasar, El Cortesano tradvəৃido por Boscan en nvestro vulgar Casellano, nueuamente aogra corregido (Amberes: Philippo Nucio, 1574).

Covarrubias Horozco, Sebastián de, Tesoro de la lengua castellana o española, edición integral e ilustrada de Ignacio Arellano y Rafael Zafra (Pamplona: Universidad de Navarra y Editorial Iberoamericana, 2006).

Frugoni, Chiara, La fortuna di Alessandro Magno dall'antichità al Medioevo (Firenze: La Nuova Italia, 1978).

García García, Cristina, "La divinización de Alejandro Magno", Revista Estudios 35 (2017): 362-389.

Goukowsky, Paul, Essai sur les origines du mythe d'Alexandre (336-270 a.C.). Vol. I: Les origines politiques (Nancy: Université de Nancy, 1978).

Goukowsky, Paul, Essai sur les origines du mythe d'Alexandre (336-270 a.C.). Vol. II: Alexandre et Dionysos (Nancy: Université de Nancy, 1981).

Gómez Espelosín, Francisco Javier, En busca de Alejandro. Historia de una obsesión (Alcalá de Henares: Universidad de Alcalá, 2015).

Green, Peter, "Caesar and Alexander: Aemulatio, Imitatio, Comparatio", American Journal of Ancient History 3/1 (1978): 1-26.

Lane Fox, Robin, Alejandro Magno. Conquistador del mundo (Barcelona: Acantilado, 2007). 
Massip, Francesc, "El toisón de oro en escena: espectáculo e imagen al servicio de la casa de Borgoña," en $A$ la búsqueda del Toisón de Oro. La Europa de los Príncipes. La Europa de las ciudades, eds. Eduard Mira y An Delva (Valencia: Generalitat Valenciana, 2007).

Mínguez, Víctor y Rodríguez Moya, Inmaculada, El tiempo de los Habsburgo. La construcción artística de un linaje imperial en el Renacimiento (Madrid: Marcial Pons, 2020).

-, Emulating Alexander. Studies on the visual legacy of the King of Macedonia from the Renaissance to the Age of Revolution (Leiden: Brill, en prensa).

Morán Turina, Miguel, La memoria de las piedras. Anticuarios, arqueólogos y coleccionistas de antigüedades en la España de los Austrias (Madrid: Centro de Estudios Europa Hispánica, 2010).

Plutarco, Vida de César, edición de Eduardo Fernández (Madrid: Rialp, 2016).

Porreño, Baltasar, Museo de los Reyes sabios que an tenido las Naciones del Orbe, y los libros que ellos y los emperadores y infantes an escrito y sacado a luz.

Ripa, Cesare, Iconología (Madrid: Akal, 1996).

Rodríguez Adrados, Francisco, "Las imágenes de Alejandro", en Alejandro Magno. Hombre y mito, eds. Jaime Alvar y José María Blázquez (Madrid: Actas, 2000).

Suetonio, Vida de los doce césares, edición de Mariano Bassols de Climent (Madrid: CSIC, 1996).

Torrione, Margarita, Alejandro, genio ardiente. El manuscrito de Cristina de Suecia sobre la vida y hechos de Alejandro Magno (Madrid: Antonio Machado Libros, 2011).

Vallejo, Irene, El infinito en un junco. La invención de los libros en el mundo antiguo (Madrid: Siruela, 2019).

Will, Wolfgang, "El mito de Alejandro", en Alejandro Magno. Encuentro con Oriente, ed. Alfried Wieczorek (Madrid: Canal de Isabel II, 2010). 
Recibido: 12 de abril de 2021

Aceptado: 14 de mayo de 2021 